\title{
APPLICATION OF MAGNETORHEOLOGICAL ELASTOMERS FOR PERFORMANCE CONTROL OF CUSHIONING SYSTEMS FOR WHEELED VEHICLES
}

The purpose of the work is to study the influence of the control of the elastic and damping characteristics of the cushioning system based on the use of magnetorheological elastomers on the smoothness of the course of wheeled transport vehicles. The technique. The research used the methods of: magnetic field theory, the theory of vehicle suspension, experiment theory planning, and the FEMM code for studying magnetic field characteristics and mathematical modeling of wheeled vehicle movement along roughness in the Delphi environment. Results. Designed, researched and patented designs of elastic hinges of the suspension arms with magnetorheological elastomers. The relative boundaries of changes in the elastic modules and losses of these hinges are determined when controlling the characteristics of the suspension in order to improve the smoothness of the wheeled vehicle. Scientific novelty. For the first time, the feasibility of using magnetorheological elastomers to control the elastic and damping characteristics of the cushioning system of wheeled vehicles has been investigated, and the requirements for control laws have been determined, which make it possible to increase smoothness by more than $40 \%$; it is established that the control of the loss modulus has a greater effect on the improvement of smoothness of motion than the control of the elastic modulus. Practical value. The design has been developed and the relative boundaries of changes in the modules of elasticity and loss of hinges with magnetorheological elastomers during their control have been determined, which will make it possible to formulate requirements for elastomers when developing promising hinge designs for vehicle suspension systems. References 21 , figures 18. Key words: magnetorheological elastomer, control magnetic field, modulus of elasticity, loss modulus, wheeled vehicle, cushioning system, elastic hinges, suspension performance control.

Метою роботи є дослідження впливу керування пружними та демпфіруючими характеристиками системи підресорювання на основі використання магнітореологічних еластомерів на плавність ходу колісних транспортних засобів. Методика. При дослідженнях використано методи: теорії магнітного поля, теорії підресорювання транспортних засобів, теорії планування експерименту, а також пакет Ғетт для дослідження характеристик магнітного поля та математичне моделювання руху колісних транспортних засобів по нерівностям у середовищі Delphi. Результати. Розроблено, досліджено та запатентовано конструкцї̈ пружних шарнірів важелів підвіски 3 магнітореологічними еластомерами. Визначено відносні межі зміни модулів пружності та втрат даних шарнірів при здійсненні керування характеристиками підвіски для забезпечення підвищення плавності ходу колісного транспортного засобу. Наукова новизна. Вперше досліджено доцільність застосування магнітореологічних еластомерів для керування пружними та демпфіруючими характеристиками систем підресорювання колісних транспортних засобів та визначено закони керування, які дозволяють підвищити плавність ходу більще ніэ на 40 \%; встановлено, що керування модулем втрат в більшій мірі впливає на підвщщення плавності ходу, ніжс керування модулем пружності. Практична цінність. Розроблено конструкції та визначено відносні межі змін модулів пружності та втрат шарнірів із магнітореологічних еластомерів при здійсненні їх керування, щцо дозволить формулювати вимоги до еластомерів при розробці перспективних конструкцій шарнірів для систем підресорювання транспортних засобів. Бібл. 21, рис. 17.

Ключові слова: магнітореологічний еластомер, керуюче магнітне поле, модуль пружності, модуль втрат, колісний транспортний засіб, система підресорювання, пружні шарніри, керування характеристиками підвіски.

Целью работы является исследование влияния управления упругими и демпфирующими характеристиками системы подресорювання на основе использования магнитореологических эластомеров на плавность хода колесных транспортных средств. Методика. При исследованиях использованы методы: теории магнитного поля, теории подрессоривания транспортных средств, теории планирования эксперимента, а также пакет Fетт для исследования характеристик магнитного поля и математическое моделирование движения колесных транспортных средств по неровностям в среде Delphi. Результаты. Разработаны, исследованы и запатентованы конструкции упругих иарниров рычагов подвески с магнитореологическими эластомерами. Определены относительные границы изменения модулей упругости и потерь данных шарниров при осуществлении управления характеристиками подвески для обеспечения повыщения плавности хода колесного транспортного средства. Научная новизна. Впервые исследованы целесообразность применения магнитореологических эластомеров для управления упругими и демпфирующими характеристиками систем подрессоривания колесных транспортных средств и определены требования к законам управления, которые позволяют повысить плавность хода более чем на $40 \%$; установлено, что управление модулем потерь в большей степени влияет на повышение плавности хода, чем управление модулем упругости. Практическая ценность. Разработана конструкция и определены относительные границы изменений модулей упругости и потерь шарниров с магнитореологическими эластомерами при осуществлении их управления, что позволит сформулировать требования к эластомерам при разработке перспективных конструкций шарниров для систем подрессоривания транспортных средств. Библ. 21, рис. 17.

Ключевые слова: магнитореологический эластомер, управляющее магнитное поле, модуль упругости, модуль потерь, колесное транспортное средство, система подрессоривания, упругие шарниры, управление характеристиками подвески.

Problem definition. One of the promising directions for further enhancing the smoothness of vehicles when driving on rough terrain at high speeds is to control the

characteristics of their cushioning systems (CS). However, well-known traditional solutions of controlled

(C) V.V. Dushchenko, V.G. Masliev, R.A. Nanivskyi, A.O. Masliev 
CS joints are characterized by complexity, high cost and unreliability, which significantly impedes their implementation on serial models of vehicles. One of the main reasons for this is the invariance of the physicochemical properties and characteristics of the traditional materials used at the CS joints as a working body. A possible solution to this problem is to apply new, alternative, so-called smart materials, which can change their properties under the influence of external control influences. In particular, these include magnetoreological elastomers (MREs), the modulus of elasticity and loss modulus of which may change under the influence of a control magnetic field. The development of new technical solutions for the controlled CS joints with the aim of improving the smooth running of the vehicle, simplifying their design, providing the required speed of control at moderate power consumption is an urgent scientific problem to which the presented research is directed.

Analysis of scientific publications. In [1-3], the technology of MRE production is presented: to the matrix (of ordinary or silicone rubber, polyurethane, etc.), they add a certain amount (up to $40 \%$ by volume) of the filler - ferromagnetic particles, for example, carbonyl iron, of size from 5 to 40 microns. The mixture is polymerized at temperature of about $150{ }^{\circ} \mathrm{C}$. If this process occurs under the action of a magnetic field, then a MRE with anisotropic properties is obtained. Without field an isotropic MRE is obtained.

In [4], it was experimentally proved that at harmonic deformations of samples of MRE with frequencies of $1 \ldots 50 \mathrm{~Hz}$, the application of the magnetic field increases their damping properties in times.

In [5], the influence of the magnetic field on samples of MRE at a strain rate of $10 \mathrm{~Hz}$ is investigated. The damping properties increased from 4 to 18 times, depending on the size and concentration of the magnetic particles and the value of the flux density of the imposed magnetic field. Saturation of MRE occurred at $600 \ldots 800 \mathrm{mT}$.

The work [6] investigates a damper created on the basis of MRE and intended for vibration protection of precision equipment. It is proved that the damper performance, which was $0.5 \mathrm{~s}$, depends on the time of transients in MRE. The speed can be adjusted by changing the current in the control coil.

In [7], a comparative evaluation of different types of dampers for precision equipment, including ones on the basis of MRE, was carried out and its advantages were proved. The damping efficiency increases with the increase in the volume concentration in the MRE of the magnetic particles.

In [8], samples of MRE were investigated, a matrix of which made of natural rubber, and carbonyl iron $(11 \%$ by volume) with $3.5 \mu \mathrm{m}$ particles was selected as the filler. The matrix was polymerized under the action of an external magnetic field up to $1 \mathrm{~T}$ to obtain the anisotropic properties of MRE. A sample with isotropic properties was also investigated. In samples with more anisotropic properties, the increase of the shear modulus when applying a control magnetic field $(0 \ldots 600 \mathrm{mT})$ increased faster.
In [9], an increase of the shear modulus in naturalrubber-based MRE samples was found to be up to $130 \%$, and much more on silicone rubber.

In [10], samples of IRE with carbonyl iron content up to $40 \%$ (by volume) with a particle size of $1 \ldots 10 \mu \mathrm{m}$ were investigated. It is proved that with increasing volume concentration of filler particles the absorption efficiency of vibration energy by the damper increases. The control of the damper stiffness of MRE by means of control current is confirmed.

The analysis of the presented works shows that the range of changes in the modulus of elasticity and loss modulus of MRE under the action of a magnetic field gives the prospect of their application in the control systems of characteristics of CS wheeled vehicles, but studies of the magnetic and mechanical properties of MRE are still in their infancy:

- samples of mainly small sizes and their small deformations were investigated: since a magnetic field of about $1 \mathrm{~T}$ is required to obtain the desired effect, samples of the MRE were executed with a size in the direction of the magnetic flux density vector not exceeding $1 \mathrm{~mm}$. Accordingly, characteristics studies are consistent with samples with such parameters;

- the performance of control processes is poorly researched and depends on the correlation of the viscosity and elastic properties of the MRE;

- the relationship of the growth of the modulus of elasticity and the loss modulus on the action of the magnetic field has not been sufficiently investigated.

Therefore, the goal of the work is to study the influence of the control of the elastic and damping characteristics of the CS based on the use of MRE on the smooth running of wheeled vehicles.

Tasks that need to be accomplished to achieve this goal:

- to produce samples of the MRE with parameters that are suitable for research and use in the CS;

- to develop and create a stand for magnetic field influence studies on elastic and damping characteristics of IRE specimens;

- to develop and create up-to-date measuring instruments for research;

- to carry out experimental researches in the conditions of the stand of influence of the magnetic field on the static and dynamic characteristics of the samples of MRE, including on the control speed and the ratio of the modulus of elasticity and loss modulus during the action of the control magnetic field;

- to develop the design of the joint with the control device on the basis of MRE for the hinge of the CS lever;

- to carry out, by computer simulation, comparative studies of the smooth running of a serial wheeled vehicle with one equipped with a control system based on the use of MRE in the CS;

- to develop recommendations for the use of MRE to control the elastic and damping characteristics of CS of wheeled vehicles.

Research methodology. In the general case, the CS of wheeled vehicles is composed of elastic elements, damping devices (shock absorbers) and guides in the form 
of levers that connect the wheels through the elastic rubber hinges with the body of the vehicle. The rigidity and damping properties of these hinges affect the suspension characteristics, and therefore the smooth running of the vehicle.

Thus, by replacing in the hinges of rubber with MRE, it is possible to implement control of the elastic and damping characteristics of the suspension as a whole.

The scheme of two-lever suspension of wheeled vehicle is shown in Fig. 1, where the elastic hinges 4 of levers are made of MRE. In order to control their elastic and damping properties, electromagnets are placed at the ends of the hinges, which create a control magnetic field.

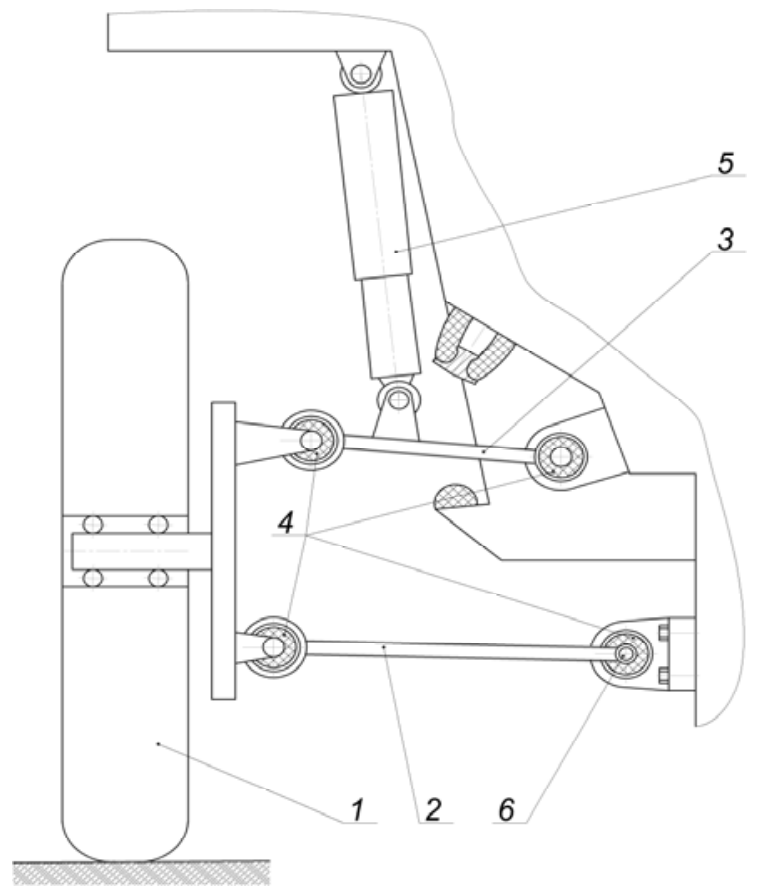

Fig. 1. Scheme of two-lever suspension of the vehicle: 1 -wheel; 2 -lower lever; 3 -upper lever; 4 -elastic hinges of MRE with control electromagnets; 5 - damping device

(shock absorber); 6 - elastic element (torsion)

To calculate the magnetic flux density, to study the uniform distribution of the magnetic field in the sleeves of MRE of hinges 4, and to choose their rational design, a software package FEMM was used. The finite element mesh was created in automatic mode, with the possibility of adjusting it to refine the results of the studies.

The initial data for the research were the drawings of the elastic sleeve, the physical characteristics of the materials of the components of the magnetic circuit, and the magnetomotive force created by the current that feeds the coil. The magnetization curves for selected commercially available grades of steel and MRE are shown in Fig. 2, 3 according to [11, 12].

To prevent overheating, a current density in the coil wire of $<10 \mathrm{~A} / \mathrm{mm}^{2}$ was limited, with action time of $<10 \mathrm{~s}$.

Several variants of the design of an elastic hinge of MRE have been considered and investigated [10, 13-15]. The most rational in terms of manufacturing technology, placement and maintainability option was chosen [15], which is shown in Fig. 4.

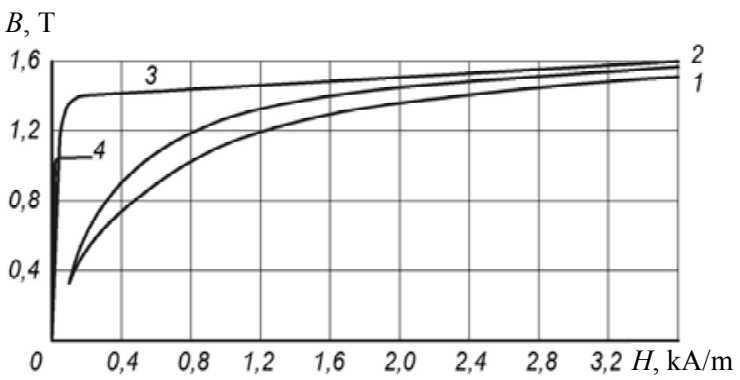

Fig. 2. Magnetization curves: 1 - cast steel; 2 - electrical steel E11; 3 - sheet steel, 4 - perm

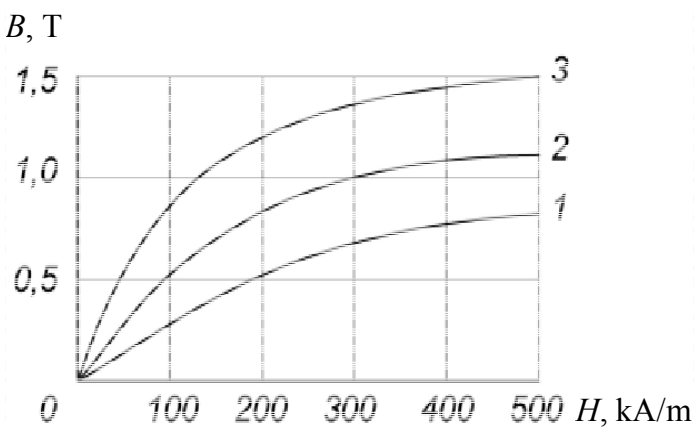

Fig. 3. Magnetization curves: 1 - MRE with a content of $20 \%$ carbonyl iron by volume; 2 - MRE containing $40 \%$ by volume of carbonyl iron; 3 - pure carbonyl iron powder

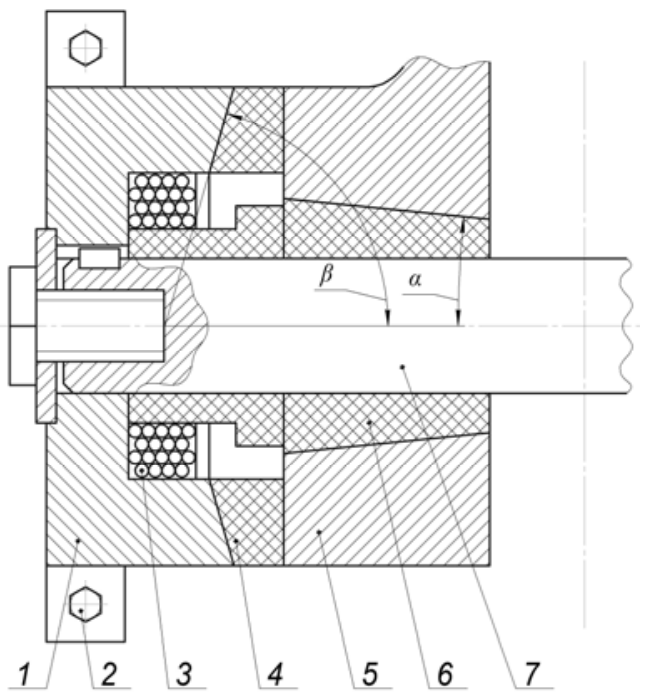

Fig. 4. Design of the hinge of MRE: 1 - bracket; 2 - bolts of fastening to the case of the vehicle; 3 - coil; 4 - end elastic element of MRE; 5 - suspension lever; 6 - radial elastic element of MRE; 7 - torsion

The results of the study using the FEMM software package proved that in order to ensure the most uniform distribution of magnetic flux density in the end 4 and radial 6 elastic elements made of MRE (Fig. 4), one of the surfaces in each of them must be made in the shape of a cone.

Variation of the angle of inclination of the cones to the axis of the torsion 7 allowed to obtain their rational values, in which the magnetic flux density in the end 1 and radial 2 elastic elements of MRE was distributed fairly uniformly, and the deviation from the average within $10 \%$ (Fig. 5). 


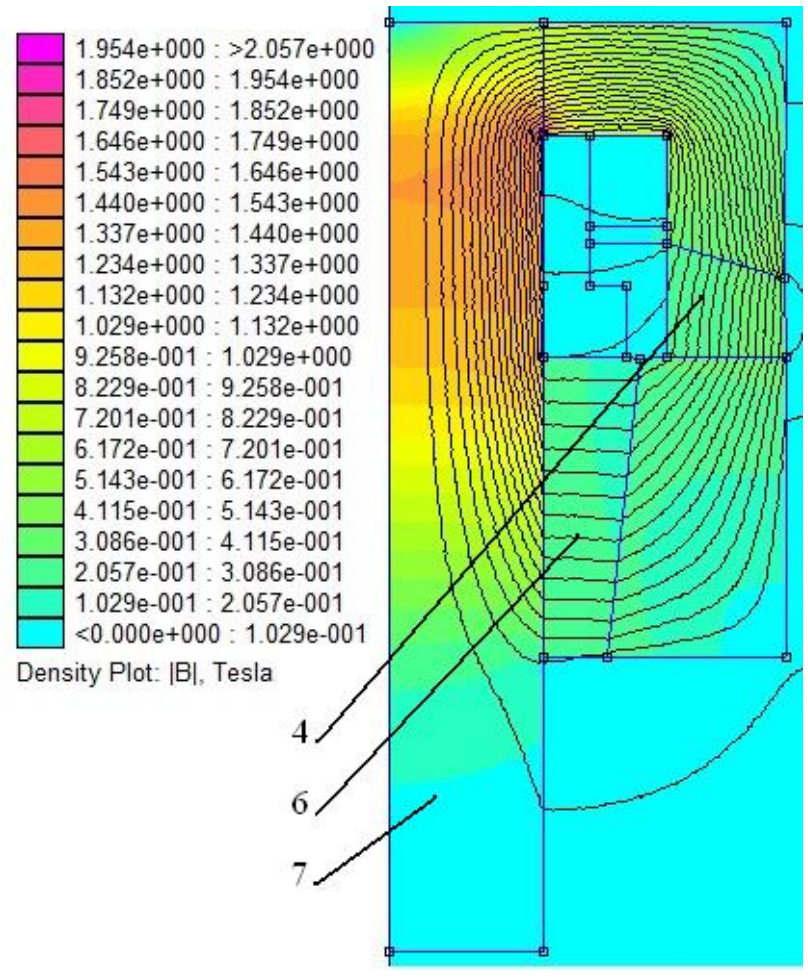

Fig. 5. Results of magnetic field distribution studies:

4 - end elastic element of MRE, 6 - radial elastic element of MRE; 7 - torsion (numbering of positions according to Fig. 4)

According to the acceptable overall parameters of the hinge and its coil 3 (Fig. 4), the value of the allowable (by heating) magnetomotive force was $F=1500 \mathrm{~A}$. This allowed to obtain magnetic flux density in the elastic elements 4 and 6 within $B=0.5 \ldots 0.6 \mathrm{~T}$ (Fig. 5). According to [18], the modulus of elasticity and the coefficient of rigidity should increase by $25 \%$ and the damping factor by $18 \%$, which is insufficient to achieve the stated research objective. However, other sources claim that this increase can be significantly higher $[4,9]$. The reason for this contradiction is that the relative magnetic permeability of MRE is small: at $40 \%$ of carbonyl iron by volume and $B=0 \ldots 0.5 \mathrm{~T}, \mu_{\mathrm{r}} \approx 10$, and at $B=0.5 \ldots 1 \mathrm{~T}$ it is still decreases to $\mu_{\mathrm{r}} \approx 4$ (Fig. 3).

In turn, in [19] it is recommended to increase the magnetic permeability for practical use of MRE. Thus, this contradiction requires careful experimental verification, which was carried out at a specially designed stand, shown in Fig. 6 [16, 17].

This stand allows to carry out a wide range of studies of the influence of the magnetic field on the modulus of elasticity, displacement and loss of samples of MRE. The influence of such external factors as gravity and pull force of electromagnets is practically excluded, and the closed magnetic circuit of ferromagnetics increases the magnetic flux density (Fig. 7). Electrotensometry method was used for research, measuring devices were created on the basis of modern microprocessor technologies (Fig. 8).

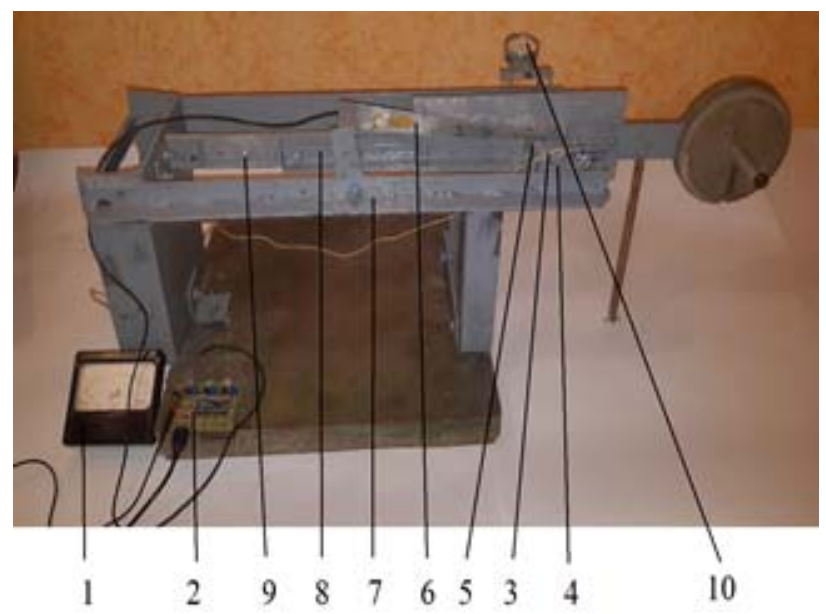

$a$

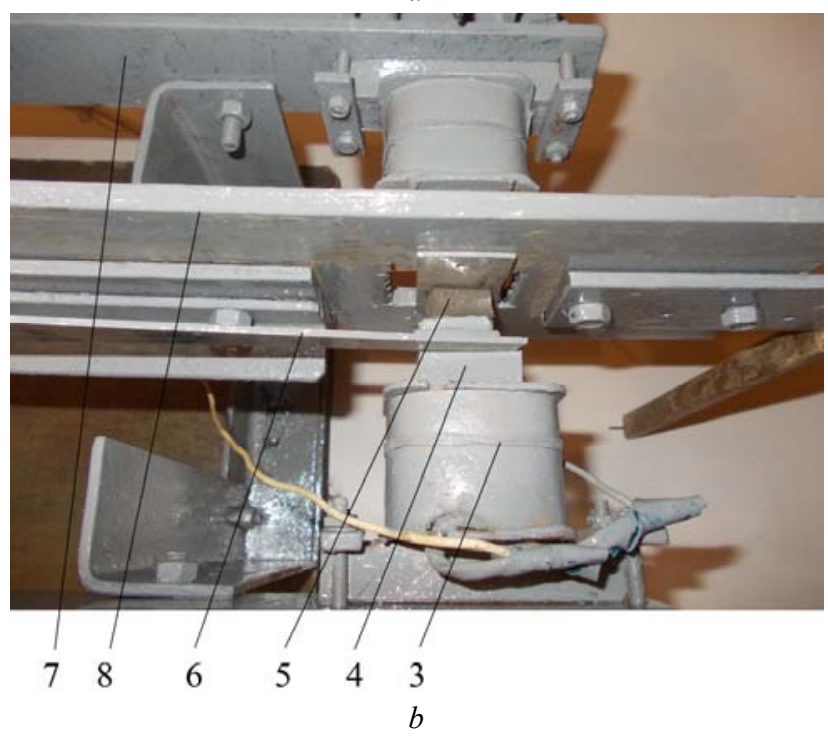

Fig. 6. Stand for investigation of mechanical characteristics of samples of MRE $(a)$ and the joint where samples of MRE are installed $(b)$ : 1 - ammeter; 2 - strain gauge with analog-todigital converter (ADC); 3 - coils for excitation of magnetic flux; 4 - cores of the coils; 5 - elastic samples of IRE under study; 6 - deflection meter with strain gauges; 7 - magnetic core; 8 - rigid range; 9 - flexible plate made of non-magnetic material; 10 - hour indicator

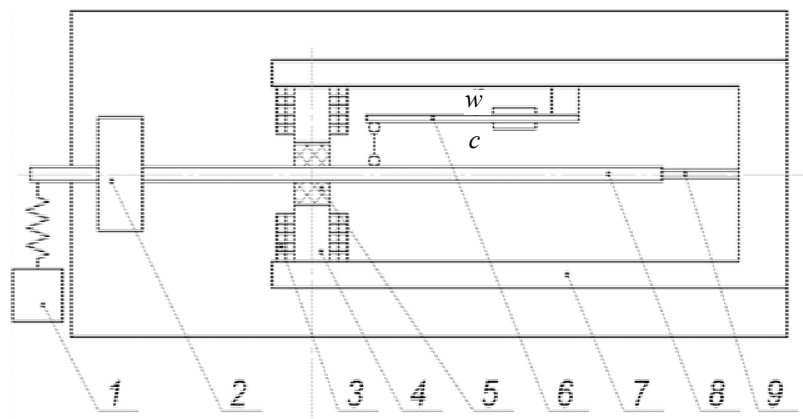

Fig. 7. Scheme of stand for research of samples of MRE: 1 - mechanical eccentric vibrator (frequency range $0 \ldots 20 \mathrm{~Hz}$; oscillation amplitude $1 \mathrm{~mm}$ ); 2 - oscillating mass; 3 - coils for excitation of magnetic flux; 4 - cores of the coils; 5 - elastic samples of MRE under study; 6 - deflection meter with strain gauges ( $\mathrm{w}$ - working, $\mathrm{c}$ - compensation); 7 - magnetic core; 8 - rigid range; 9 - flexible plate made of non-magnetic material 


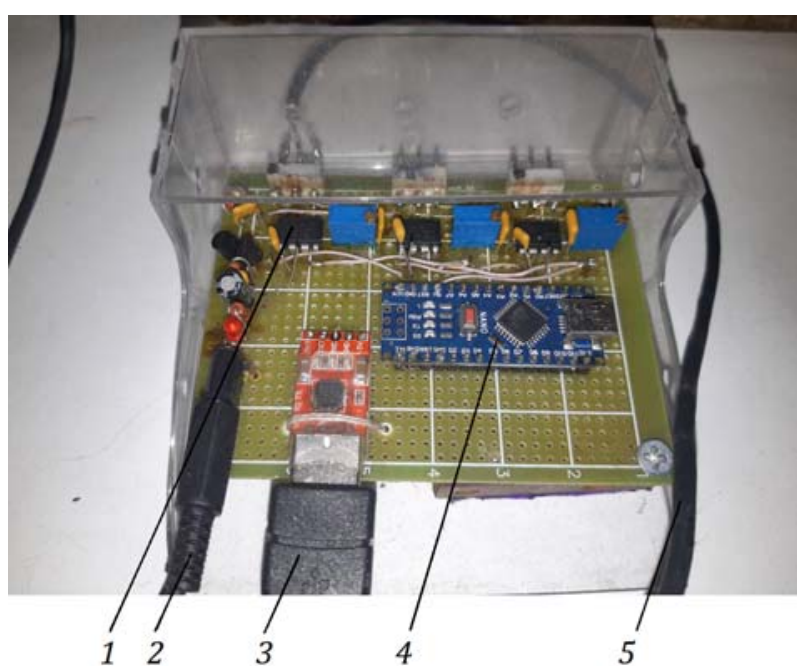

Fig. 8. Measuring device: 1 - analog current amplifiers from strain gauges; 2 - calculator; 3 - shielded cable; 4 - USB connector of the digital signal output to the computer; 5 - power cable

The frequency range of the measuring device within which the gain had a deviation within $\pm 1.5 \%$ was $0 \ldots 20 \mathrm{~Hz}$. The circuit of the measuring channel is shown in Fig. 9.

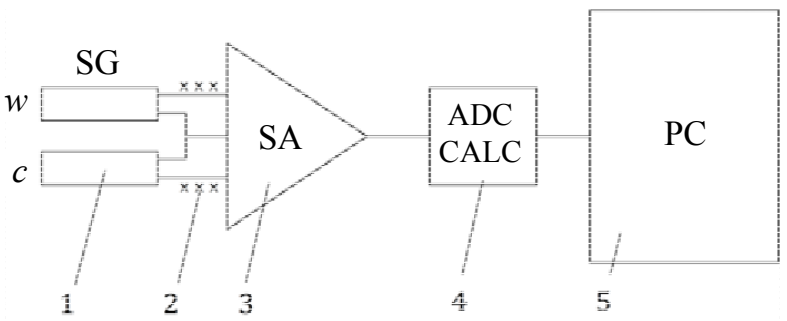

Fig. 9. Circuit of the measuring channel: $1-\mathrm{SG}-$ strain gauges of deflection meter ( $\mathrm{w}$ - working, c - compensation);

2 - shielded cable; 3 - analog strain amplifier AD 625;

4 - ATMEGA 328 calculator with ADC; 5 - personal computer

Samples 5 (Fig. 7) were studied in the shape of rings with an outer diameter of $20 \mathrm{~mm}$, a thickness of $10 \mathrm{~mm}$ and a central hole with a diameter of $6 \mathrm{~mm}$, which were made of MRE by known technology [6].

Silicone rubber was used as the MRE matrix. The carbonyl iron content by volume is $40 \%$, the size of the magnetic particles is $5 \ldots 10$ microns.

To create the anisotropic MRE structure, the polymerization of the sample material was carried out in a thermal cabinet at $160{ }^{\circ} \mathrm{C}$ for 2 hours and in the presence of a magnetic field $B=0.6 \mathrm{~T}$, the vector of which was directed to the surfaces of the samples in the same direction as the magnetic flux density vector of the control magnetic field would be directed (in order to obtain its greater influence on the characteristics [6]).

Before and after the measurements, a direct calibration of the measuring channel was carried out by displacing the rigid range 8 one way and the other with the help of an elastic dynamometer, which caused deformation of the samples 5, which were measured by the clock indicator 10 (Fig. 6). Scale factor $K=0.067$ was obtained.

Analysis of the static characteristics showed that the flux density of the control magnetic field $B=0.6 \mathrm{~T}$ caused an increase in the stiffness coefficient of 1.75 times and in the damping factor of 4.4 times (the stiffness coefficient was calculated at the highest values of $F$ and $x$, and the damping coefficient by hysteresis loops areas). Therefore, the damping in the samples increased almost four times faster than their rigidity (Fig. 10).

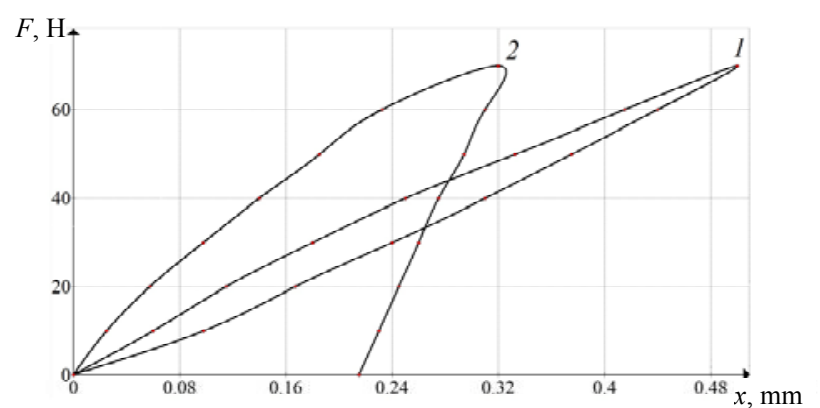

Fig. 10. Static loading characteristics of MRE specimens: 1 - without magnetic field; 2 - magnetic field $B=0.6 \mathrm{~T}$

Thus, the results obtained are different from those given in [18], but do not contradict known studies, but refine them. This confirms that we have chosen the right MRE production technology and research direction.

When performing dynamic tests, the vibrations were excited by the mechanical vibrator 1 , which through the spring transmitted a harmonic force to the rigid range 8 and rocked it together with the mass 2 to obtain resonance amplitudes.

Figures 11, 12 show the oscillograms of the eigen oscillations of mass 2 on elastic specimens 5 of MRE.

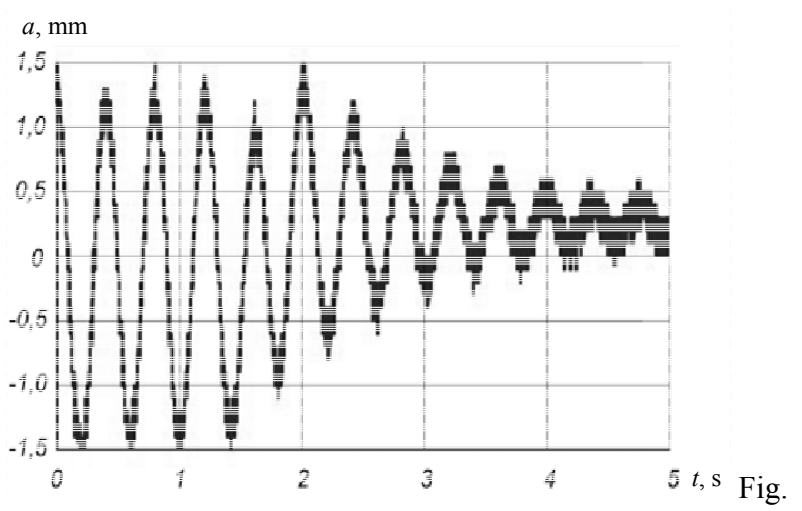

11. The oscillogram of vibrations of mass 2 on samples 6 in the absence of a control magnetic field

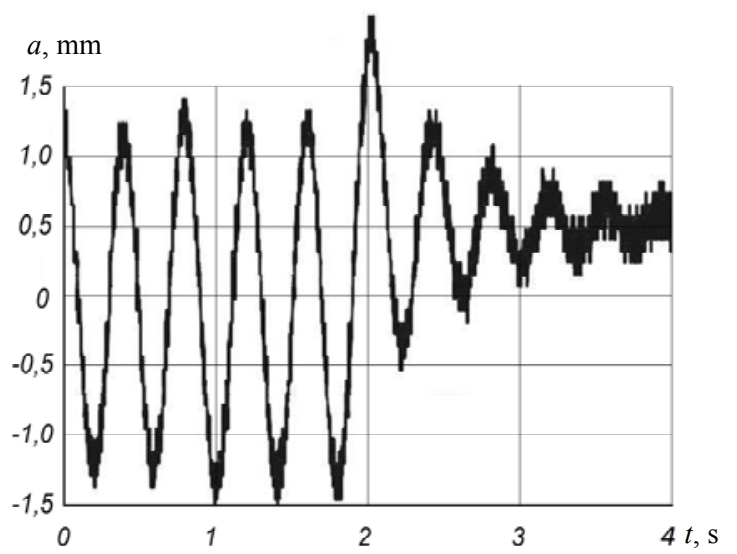

Fig. 12. The oscillogram of vibrations of mass 2 on samples 6 in the presence of a control magnetic field $B=0.6 \mathrm{~T}$ 
The analysis of the oscillograms showed that when the control magnetic field was switched on, the time constant decreased from $1.48 \mathrm{~s}$ to $0.78 \mathrm{~s}$, i.e. the speed of oscillation damping improved. The transient was practically completed in $3 \cdot 0.78=2.34 \mathrm{~s}$.

At the same time, there was an increase in the coefficient of rigidity of the samples by about $25 \%$, which caused an increase in the frequency of natural oscillations from 2.5 to $2.7 \mathrm{~Hz}$, i.e. by $8 \%$. The damping factor increased by $118 \%$ (from 0.038 to 0.083 ), i.e. 4.7 times higher than the stiffness factor. This is close to the results of static tests and well-known studies $[4,18]$.

Figure 13 shows a sample oscillogram of forced (close to resonant) vibrations of mass 2.

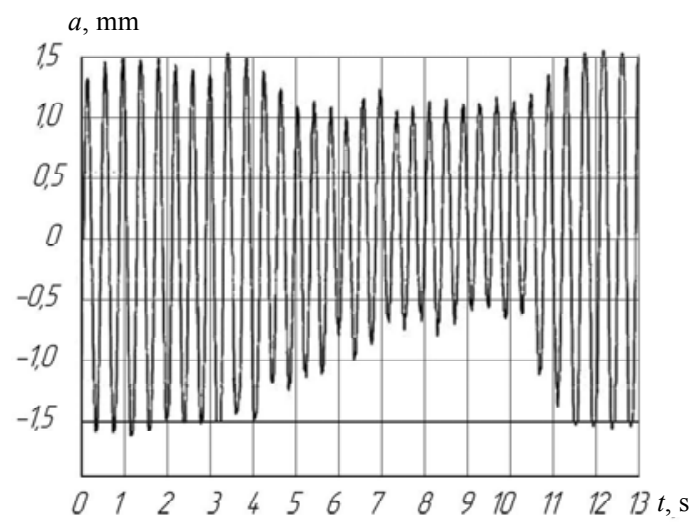

Fig. 13. The oscillogram of the forced vibrations of mass 2 on elastic specimens 5 of MRE at the modes «absence - switching on - absence» of the control magnetic field

With the help of the vibrator 1, the system was introduced into the mode of resonant vibrations, and then a current was supplied to the coils 3 (Fig. 7), which created a control magnetic field with flux density $B=0.6 \mathrm{~T}$. The vibration amplitudes were halved due to the increase in damping in elastic specimens 5 of MRE.

After switching off the magnetic field, the system returned to resonant vibrations mode, and their amplitudes doubled, i.e. to the initial value. The duration of transients was about $2.3 \mathrm{~s}$.

To further reduce the amplitude of the oscillations, it is necessary to increase the magnetic flux density of the control field. To prevent the increase of heat losses, it is advisable not to increase the current in the coils, but to create an MRE with increased magnetic permeability.

According to the results of studies of hinges of MRE, 4 patents of Ukraine are received [14, 15, 17, 20].

For the theoretical substantiation of the recommendations for practical application of the obtained results, comparative studies of the smoothness of the running of two wheeled vehicles were carried out: serial and the same, but equipped with the system of control of SC characteristics based on the use of hinges of MRE in suspension levers (Fig. 1, 4).

The smoothness of the running of these vehicles was investigated by the method of computer simulation of their motion on sinusoidal road profiles of bumps, in accordance with the accepted methodology in the field, by calculating and constructing the speed characteristics of the vehicles [21]. These characteristics represent the dependence of the height of the bumps $h$ (passage height), which the vehicle is able to overcome with vertical acceleration in the locations of people not exceeding $3 \mathrm{~g}$, $\left(29.43 \mathrm{~m} / \mathrm{s}^{2}\right)$, due to ergonomic requirements, on the speed of movement. Speed characteristics are calculated for three bumps lengths: $1.5 L, 2 L$, and $2.5 L$, where $L$ is the vehicle's base.

The resonance bands are characteristic of the speed characteristics, when the frequencies of the eigen oscillations of the cushioned body of the vehicle coincide with the frequency of perturbations from bumps. The passage height of the bumps corresponding to the resonance has the least value and is called the minimum passage height of the bumps. In accordance with the current requirements for smooth running of the vehicle of high passability, the level of minimum passage heights of bumps should be not less than $0.19 \ldots 0.24 \mathrm{~m}$, depending on the given average speed of movement on the terrain.

To prevent overheating of the electromagnets, the control of the characteristics of the CS will be applied only when overcoming sections of terrain with difficult road conditions, which usually have a length of $30 \ldots 50 \mathrm{~m}$, and overcoming which will take time no more than $10 \mathrm{~s}$, while maintaining the speed of movement.

An experimentally verified mathematical model of wheeled vehicle motion was used for the research [21], which was refined in accordance with the control system utilization and implemented in the Delphi environment.

Let us evaluate the influence of the characteristics of the elastic hinges of the CS of the serial vehicle on the smoothness of the running. From Fig. 14 the following follows. In the case where the hinge loss modulus is zero, curves 2 , there is a decrease in the minimum passage heights of bumps at all resonant speeds of motion approximately equal to $6.6 \mathrm{~m} / \mathrm{s}, 8.9 \mathrm{~m} / \mathrm{s}$, and $11 \mathrm{~m} / \mathrm{s}$, respectively, for bumps of $1.5 \mathrm{~L}, 2 \mathrm{~L}$, and $2.5 \mathrm{~L}$ length. This decrease occurs from the level of $0.12 \ldots 0.14 \mathrm{~m}$ to the level of $0.09 \mathrm{~m}$, i.e. the smoothness of the running deteriorates at $25 \ldots 36 \%$.

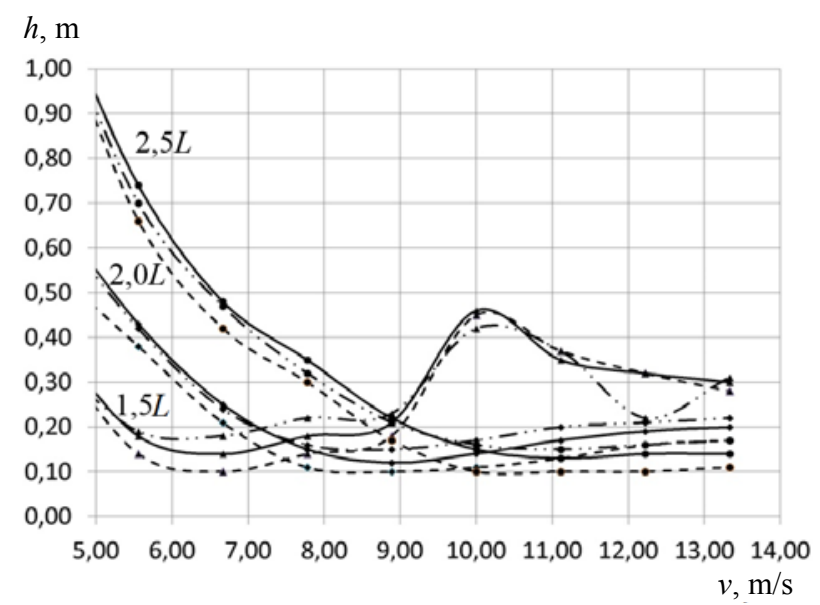

Fig. 14. CS speed features: impact assessment of elastic suspension rubber hinges:

- $1-$ hinges with original characteristics;

- - - $\quad 2$ - the hinge loss modulus is zero;

- - - 3- the hinge elastic modulus is zero 
Worsening also occurs at pre-resonance speeds for all bump lengths. At resonance speeds, the smoothness of motion deteriorates at bumps of lengths of $2 \mathrm{~L}$ and $2.5 \mathrm{~L}$ and remains unchanged at bumps of length of $1.5 \mathrm{~L}$.

In turn, the variant «modulus of elasticity of the hinges is zero», curves 3, leads to an increase in the minimum passage heights of bumps at resonant speeds of movement from the level of $0.12 \ldots 0.14 \mathrm{~m}$ to the level of $0.14 \ldots 0.17 \mathrm{~m}$, i.e., smoothness of running improves by $17 \ldots 21 \%$. At the same time, at pre-resonance speeds, the smoothness of running slightly decreases, and at resonance speeds it improves, at bumps of length of $2 L$ and $2.5 \mathrm{~L}$, and worsens at $1.5 \mathrm{~L}$.

Thus, the characteristics of the elastic hinges of the vehicles CS levers significantly influence its smooth running, and by applying control of their loss and elasticity modules based on the use of MRE, it is possible to significantly improve the quality of cushioning.

In order to reduce the number of control electromagnets and simplify the design of the suspension, in further studies the use of the control of the characteristics of the hinges of MRE only of the lower levers of the suspension, which are coupled with the torsions are considered.

Figure 15 shows the results of the study of the influence of the control of modulus of elasticity of these hinges of MRE. From the graphs it follows that in the variant «modulus of elasticity is zero», curves 2, at resonant speeds of movement, the minimum passage heights of bumps increase from the level of $0.12 \ldots 0.14 \mathrm{~m}$ to the level of $0.13 \ldots 0.15 \mathrm{~m}$. Here, the smoothness of running at pre-resonance speeds does not practically change for all lengths of bumps, and at post-resonance speeds the smoothness of running is slightly improved at bumps of length of $2 L$ and $2.5 \mathrm{~L}$ and worsens at $1.5 \mathrm{~L}$.

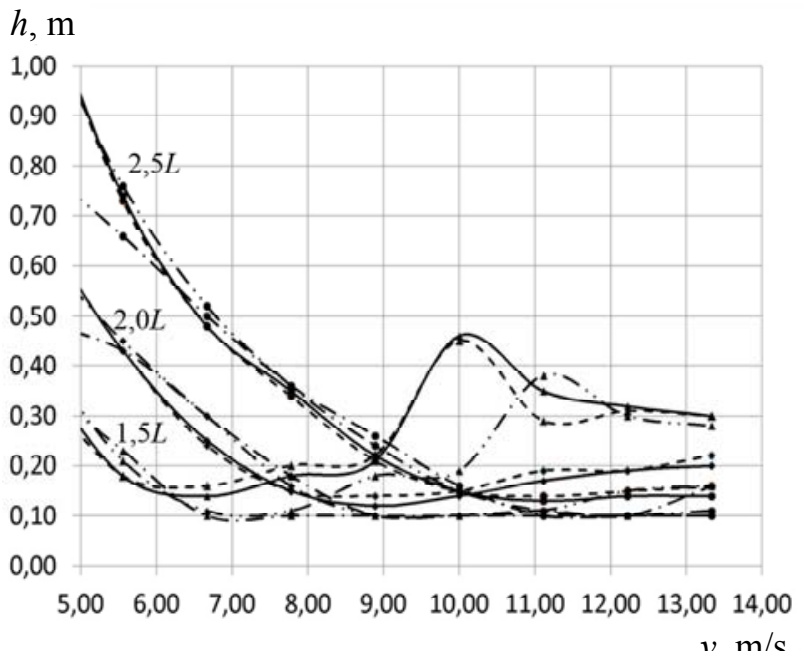

Fig. 15. CS speed features: impact assessment of the control of the modulus of elasticity of hinges of MRE (loss modulus has original value):

-1 - original modulus value;

- - - - 2 - modulus is zero;

$-\cdots-\cdot 3$ - modulus is enlarged 5 times;

$-\cdot-4$ - modulus is enlarged 10 times

In the case of increasing the modulus of elasticity of these hinges by 5 times (curves 3 ), the minimum passage heights of bumps at resonant speeds of movement decrease from the level of $0.12 \ldots 0.14 \mathrm{~m}$ to the level of $0.09 \mathrm{~m}$. Here, the smoothness of the running at the preresonance speeds increases for all lengths of bumps, and at the post-resonance speeds it deteriorates at all bumps, and especially of the length of $1.5 \mathrm{~L}$. At increasing the modulus of elasticity by 10 times (curves 4), the smoothness of the running deteriorates at almost all speeds and lengths of bumps.

Figure 16 shows the results of the study of the effect of control of loss modulus of hinges of MRE, from which it follows that in the case where the loss modulus is equal to zero, curves 2, the minimum passage heights of bumps, at resonant speeds of movement decrease from the level of $0.12 \ldots 0.14 \mathrm{~m}$ to the level $0.10 \ldots 0.11 \mathrm{~m}$. Here, the smoothness of the running deteriorates at all speeds of motion and lengths of bumps.

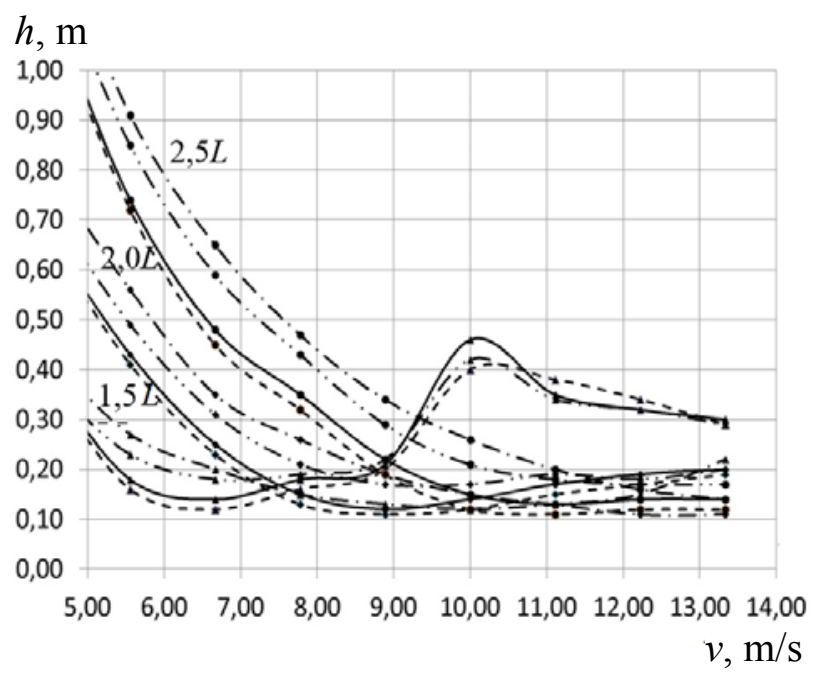

Fig. 16. CS speed features: impact assessment of the control of the loss modulus of hinges (modulus of elasticity has original value):

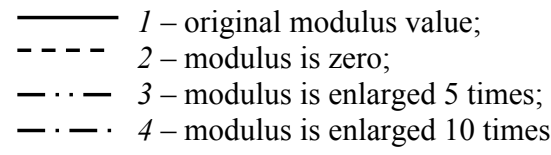

At increase of the loss modulus of these hinges in 5 times (curves 3) the minimum pass heights of bumps at resonant speeds of movement increase from the level $0.12 \ldots$ $0.14 \mathrm{~m}$ to the level $0.17 \ldots 0.18 \mathrm{~m}$, i.e. by $28.6 \ldots 41.7 \%$, which is close to the level of modern requirements $(0.19 \ldots 0.24 \mathrm{~m})$. At pre-resonance speeds, the smoothness of the running is improved at all lengths of bumps, and at the post-resonance ones it improves on bumps of lengths of $2 L$ and $2.5 L$ and slightly decreases on bumps of length of $1.5 \mathrm{~L}$.

When the loss modulus is increased by 10 times (curves 4 ) at the resonant speeds of movement, the minimum passage heights of bumps decrease slightly from the level of $0.12 \ldots 0.14 \mathrm{~m}$ to the level of $0.12 \ldots 0.13 \mathrm{~m}$. At pre-resonance speeds, the smoothness of the running is significantly improved at all lengths of bumps, at the postresonance speeds the smoothness of running is slightly impaired at the bumps of lengths of $2 L$ and $2.5 \mathrm{~L}$ and significantly worsens on the bumps of length of $1.5 \mathrm{~L}$. 
Figures 17,18 present the results of the study of the effect of joint control of loss modulus and modulus of elasticity of the hinges of MRE of the lower suspension levers on the smooth of running of the vehicle.

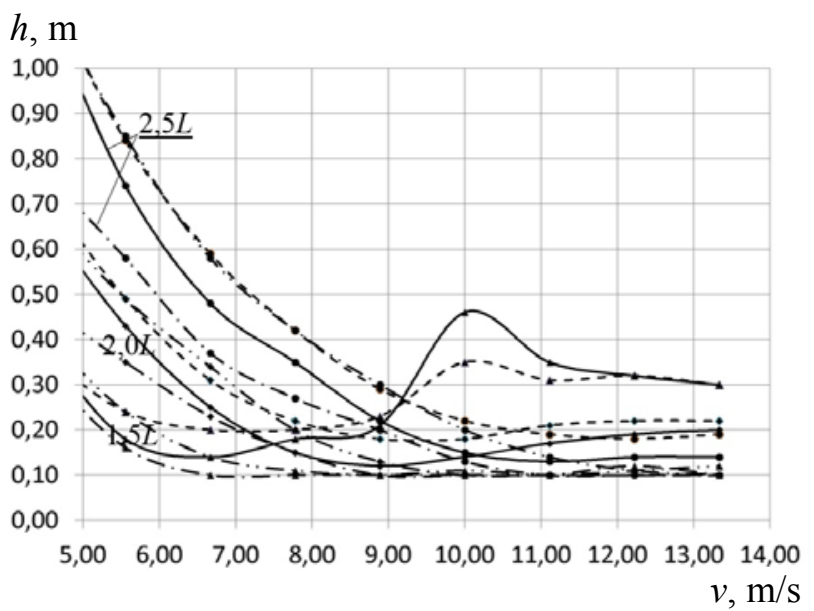

Fig. 17. CS speed features: impact assessment of the joint control of loss modulus and modulus of elasticity of lower levers hinges:

-1 - original value of loss and elasticity modules;
$----2-$ loss modulus is increased by 5 times, modulus of elasticity is zero;

- - - -3 - loss and elasticity modules increased by 5 times; $-\cdot-\cdot-4-$ loss modulus is increased by 5 times, modulus of elasticity is increased by 10 times

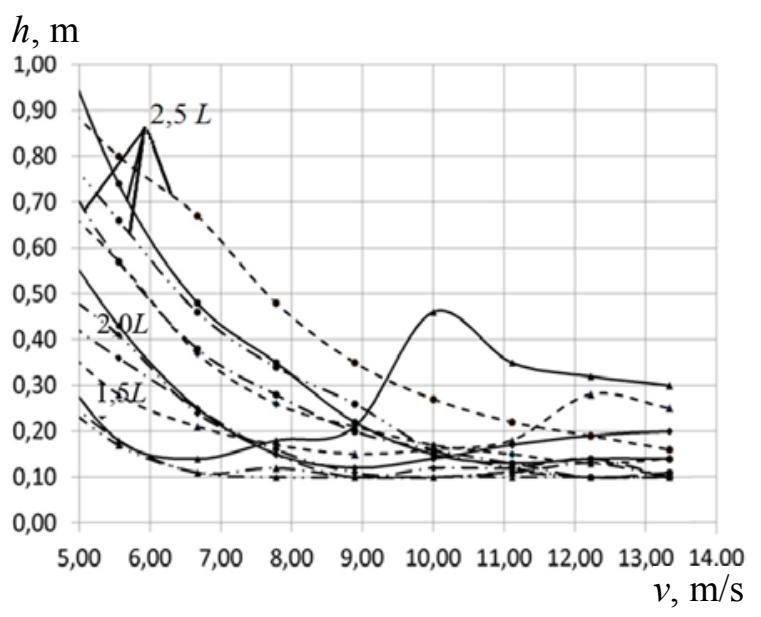

Fig. 18. SC speed features: impact assessment of the joint control of loss and elasticity modules of lower levers hinges:

- 1 - original value of modules;

- - - - - 2 - loss modulus is increased by 10 times, modulus of elasticity is zero;

$-\cdots-\cdots 3-$ loss modulus increased by 10 times, modulus of elasticity increased by 5 times;

- $\cdot-\cdot-4-$ loss and elasticity modules increased by 10 times

According to Fig. 17, for the variant «loss modulus is increased by 5 times, the modulus of elasticity is zero"», curves 2, the minimum passage heights of bumps increase from the level of $0.12 \ldots 0.14 \mathrm{~m}$ to the level of $0.17 \ldots 0.19 \mathrm{~m}$, i.e. by $35.7 \ldots 41.7 \%$, which is close to the level of modern requirements $(0.19 \ldots 0.24 \mathrm{~m})$.

The option «loss and elasticity modules increased by 5 times» (curves 3 ) allows to significantly (up to $43 \%$ ) increase the smoothness of running at pre-resonant speeds of motion at all lengths of bumps.

The option «loss modulus is increased by 5 times, the modulus of elasticity is increased by 10 times» (curves 4) leads to a deterioration of smooth running in the entire speed range, at all lengths of bumps.

From the graphs shown in Fig. 18, it follows that an increase in the loss modulus by 10 tomes (graph 2) leads to an improvement in the smoothness of running at bumps of $1.5 \mathrm{~L}$ in length at pre-resonance speeds and to a deterioration at post-resonance speeds of motion. This option ensures an increase in the minimum passage heights of bumps (at a speed of $9 \mathrm{~m} / \mathrm{s}$ ) from the level of $0.12 \ldots 0.14 \mathrm{~m}$ only to the level of $0.13 \ldots 0.14 \mathrm{~m}$, i.e. worse than in the previous case.

The variants of «loss modulus increased by 10 times, elastic modulus increased by 5 times» (graph 3 ) and «loss and elastic modules increased by 10 times» (graph 4) show that such increase of modules leads to a significant deterioration of the smooth of running throughout the speeds and bumps range.

Discussion of results. Analysis of the graphs shown in Fig. 14, proves that the characteristics of the elastic hinges of levers of the vehicles' SC significantly influence its smooth of running, and control of their loss and elasticity modules is expedient to be implemented on the vehicles. In order to reduce energy consumption and prevent overheating of the joints, this control is advisable at resonant speeds of movement when overcoming sections of terrain with difficult road conditions, without reducing the speed of movement.

It is advisable to control the loss modulus more than the elastic modulus, since increasing the latter can lead to a deterioration of the smooth of running. It is necessary to create MRE with properties where, in the case of control, an increase in the loss modulus is not accompanied by an increase in the elastic modulus.

The experimental studies carried out made it possible to increase the losses modulus in MRE samples only twice, but the calculation investigation showed the desirability of its increase by 5 times. It is possible to solve this problem either by increasing the number of controlled hinges, installing them also on the upper suspension levers, or by applying another MRE fabrication technology, which will provide a fivefold increase in the loss modulus under the action of the magnetic field with flux density of up to $1.5 \mathrm{~T}$.

The obtained values of increase (relative to serial vehicle) of loss and elasticity modules and constructed speed characteristics of vehicles allow to develop requirements for the laws of control of characteristics of hinges of MRE, depending on the mode of motion (preresonant, resonant or post-resonant) and length of bumps.

We formulate these requirements for the laws of control of the characteristics of elastic hinges of MRE in vehicles:

- control should be implemented only at resonant speeds of the vehicle;

- control is only expedient for the losses modulus of MRE of hinges of the levers of vehicles; 
- it is recommended to increase the loss modulus no more than 5 times;

- control processes must be no longer than $10 \mathrm{~s}$ and have acceptable intervals between them.

Conclusions and recommendations.

1. For the first time, samples of magnetorheological elastomers with parameters suitable for use in the hinges of levers of vehicles' cushioning systems have been manufactured.

2. The original stand was developed, the static characteristics of the stiffness and damping of the made samples are investigated on which. It is found that the control magnetic field has a greater effect on the loss modulus than on the modulus of elasticity. For the first time, it is shown that the flux density $B=0.6 \mathrm{~T}$ of the control magnetic field causes a $25 \%$ increase in the stiffness coefficient (and modulus of elasticity), which causes an increase in the frequency of natural oscillations from 2.5 to $2.7 \mathrm{~Hz}$ (by $8 \%$ ). The damping factor increased by $118 \%$ (from 0.038 to 0.083 ), i.e. 4.7 times higher than the stiffness coefficient.

3. In the course of dynamic tests on the developed stand, using manufactured modern measuring equipment, for the first time it is discovered that when the control magnetic field is switched on, the time constant of free oscillation of mass on elastic elements of magnetoreological elastomers decreased from 1.48 to $0.78 \mathrm{~s}$. The transient was almost completed in $2.34 \mathrm{~s}$. The amplitudes of the resonance vibrations of the mass on the elastic elements of the magnetoreological elastomers, when the control magnetic field $B=0.6 \mathrm{~T}$ is switched on, are halved in $2.34 \mathrm{~s}$.

4. The original designs of the controlled elastic hinge of magnetoreological elastomers and the device for creation of the control magnetic field are developed and patented. The parameters that provided a uniform (within $10 \%$ ) distribution of magnetic flux density in the sections of the hinges were determined. In order to achieve magnetic flux density in the magnetoreological elastomer at the level of $0.6 \mathrm{~T}$, the value of the magnetomotive force (15 kA) is determined, the current density in the coil of the device $\leq 10 \mathrm{~A} / \mathrm{mm}^{2}$ is selected, with operation time of up to $10 \mathrm{~s}$.

5. Requirements for control laws are formulated, which allow to increase the smooth of running of vehicles depending on speed and length of bumps by more than $40 \%$.

6 . For the first time, it has been found that the control of the loss modulus of hinges of the magnetorheological elastomers of the vehicle suspension has a greater effect on improving the smooth of running than the control of their modulus of elasticity.

7. The rational limits of the relative change of the loss modules of the hinges of the magnetoreological elastomers (not more than 5 times) during their control are determined; it is recommended to use them in formulating the requirements for magnetoreological elastomers, and to develop designs of controlled nodes of the cushioning systems.

8. According to the results of the research carried out, 4 patents of Ukraine were obtained for the method of control, the design of the hinges of magnetoreological elastomers and the suspension.

\section{REFERENCES}

1. Ginder J.M., Nichols M.E., Elie L.D., Tardiff J.L. Magnetorheological elastomers: properties and applications. Proceeding of SPIE, 1999, vol.3675, pp. 131-138.

2. Lokander M., Stenberg B. Performance of isotropic magnetorheological rubber materials. Polymer Testing, 2003, vol.22, no.3, pp. 245-251. doi: 10.1016/s0142-9418(02)00043-0.

3. Jolly M.R., Carlson J.D., Muñoz B.C., Bullions T.A. The magnetoviscoelastic response of elastomer composites consisting of ferrous particles embedded in a polymer matrix. Journal of Intelligent Material Systems and Structures, 1996, vol.7, no.6, pp. 613-622. doi: 10.1177/1045389x9600700601

4. Li W.H., Zhang X.Z., Du H. Magnetorheological elastomers and their applications. Book Chapter in Advanced Structured Materials, 2013, vol.I, pp. 357-374. doi: 10.1007/978-3-64220925-3 12.

5. Böse H., Röder R. Magnetorheological elastomers with high variability of their mechanical properties. Journal of Physics: Conference Series, 2009, vol.149, p. 012090. doi: 10.1088/1742-6596/149/1/012090.

6. Gorbunov A.I., Mikhailov V.P., Stepanov G.V., Borin D.Yu., Adrianov A.A., Temnov D.V., Semerenko D.A. Investigation of properties and new application of magnetic silicon composites. Herald of the Bauman Moscow State Technical University. Series Mechanical Engineering, 2008, no.1(70), pp. 90-107. (Rus).

7. Mihailov V.P., Shakov K.G, Selivanonko A.S., Bazinenkov A.M. Vibration isolation control in precision equipment. Science and Education of the Bauman MSTU, 2012, vol.12, no.9, pp. 112. (Rus). doi: $\mathbf{1 0 . 7 4 6 3 / 0 9 1 2 . 0 4 5 4 4 7 5 .}$

8. Chen L., Gong X.L., Li W.H. Microstructures and viscoelastic properties of anisotropic magnetorheological elastomers. Smart Materials and Structures, 2007, vol.16, no.6, pp. 2645-2650. doi: 10.1088/0964-1726/16/6/069.

9. Gong X.L., Chen L., Li J.F. Study of utilizable magnetorheological elastomers. International Journal of Modern Physics B, 2007, vol.21, no.28n29, pp. 4875-4882. doi: 10.1142/s0217979207045785.

10. Duschenko V.V., Masliev A.O. Research of the magnetic field and the choice of the construction of an elastic joint with the sleeve of the magnetorheological elastomer suspension of wheeled armored vehicle. Bulletin of NTU «KhPI». Series: Transport machine building. - 2017. no.5(1227). - pp. 173-178. (Ukr).

11. Available

at:

https://www.google.com/search?q=кривые+намагничивания+ ферромагнитных +материалов\&rlz=1C2JZAP ruUA747UA75 $\underline{5}$ (accessed 20 May 2018).

12. Krautz M., Werner D., Schrödner M., Funk A., Jantz A., Popp J., Eckert J., Waske A. Hysteretic behavior of soft magnetic elastomer composites. Journal of Magnetism and Magnetic Materials, 2017, vol.426, pp. 60-63. doi: 10.1016/j.jmmm.2016.11.048.

13. Dushhenko V.V, Masliev A.O. Improvement of the construction of hinge using magnetorheological elastomers of lever of controled suspension of the vehicle. Mechanics and mechanical engineering, 2017, no.1, pp. 90-97. (Ukr).

14. Dushhenko V.V, Masliev A.O. Pidviska z regulyuvannyam zhorstkosti ta dempfiruvannya [Suspension with adjustable stiffness and damping]. Patent UA, no.110476, 2016. (Ukr).

15. Masliev A.O., Dushhenko V.V., Ljubarskij B.G., Masliev V.G. Pidviska transportnogo zasobu [Vehicle suspension]. Patent UA, no.115131, 2017. (Ukr).

16. Duschenko V.V., Masliev A.O. Stand for experimental study of the effect of magnetic field on the elastic modulus and a module of losses of magnetorheological elastomers. Bulletin of NTU «KhPI». Series: Transport machine building, 2018, no.29(1305), pp. 46-50. (Ukr). 
17. Masliev A.O., Dushhenko V.V., Masliev V.G. Stend dlia doslidzhennia vplyvu mahnitnoho polia na kharakterystyky zhorstkosti, dempfiruvannia ta modul pruzhnosti mahnitoreolohichnykh elastomeriv [A stand for studying the influence of a magnetic field on the characteristics of stiffness, damping, and the elastic modulus of magnetorheological elastomers]. Patent UA, no.128767, 2018. (Ukr).

18. Kallio M. The elastic and damping properties of magnetorheological elastomers. VTT Publications, 2005. $149 \mathrm{pp}$.

19. Pankov A.A. Magnetodeformation effect of an elastomer with magnetized polydisperse spherical inclusions. Journal of Radio Electronics, 2015, no.4, 15 p. (Rus).

20. Dushhenko V.V., Masliev A.O., Masliev V.G. Sposib polipshennia plavnosti rukhu transportnoho zasobu [A method for improving the smoothness of the vehicle]. Patent UA, no.128458, 2018. (Ukr).

21. Aleksandrov E.E., Volontsevich D.O., Dushhenko V.V. Matematicheskoe modelirovanie processov vozmushhennogo dvizhenija agregatov $i$ sistem bronetankovoj tehniki
[Mathematical modeling of processes of disturbed movement of units and systems of armored vehicles]. Kharkiv, «KhPI» Publ., 2012. 354 p. (Rus).

Received 11.04.2019

V.V. Dushchenko ${ }^{1}$, Doctor of Technical Science, Professor,

V.G. Masliev ${ }^{1}$, Doctor of Technical Science, Professor,

R.A. Nanivskyi ${ }^{2}$, Candidate of Technical Science, Senior Instructor

A.O. Masliev ${ }^{1}$, Postgraduate Student,

${ }^{1}$ National Technical University «Kharkiv Polytechnic Institute», 2, Kyrpychova Str., Kharkiv, 61002, Ukraine, phone +380 577076355 , e-mail: dushchenko@ukr.net

${ }^{2}$ Hetman Petro Sahaidachnyi National Army Academy, 32, Heroes of Maidan Str., Lviv, 79026, Ukraine, phone +380969409559,

e-mail: roman_nani@ukr.net

How to cite this article:

Dushchenko V.V., Masliev V.G., Nanivskyi R.A., Masliev A.O. Application of magnetorheological elastomers for performance control of cushioning systems for wheeled vehicles. Electrical engineering \& electromechanics, 2019, no.5, pp. 50-59. doi: 10.20998/2074-272X.2019.5.09. 